\title{
Production and purification of TGFb-1 in CHO-Cells
}

\author{
Estabraq Abdulkerim", Sabrina Baganz ${ }^{1}$, Axel Schambach², Cornelia Kasper ${ }^{1}$, Thomas Scheper ${ }^{1}$ \\ From 22nd European Society for Animal Cell Technology (ESACT) Meeting on Cell Based Technologies \\ Vienna, Austria. 15-18 May 2011
}

\section{Introduction}

The development of chemically well defined media is a demanding task in order to create the optimal conditions for an in vitro stem cell (SC) proliferation and differentiation system. Signals that govern SC differentiation into multiple mature cell types are provided by growth factors. TGFb-1 regulates a number of biological processes, including cell differentiation and proliferation, embryonic development, apoptosis and immune responses, together with cell surface receptors and signal transduction molecules within the cell. The whole signal transduction pathway leads to the specific production of distinct proteins. In this work, TGFb-1 fragment (A280 - S391) is produced using a tailor-made $\mathrm{CHO}$ cell line $\left(\mathrm{CHO}^{\mathrm{SFS}}\right)$ and purified.

\section{Results}

Chinese Hamster Ovary cells have been subjected to lentiviral transduction of TGF beta 1 vector (figure 1) resulting in the expression of His- and HA-tagged protein from $\left(\mathrm{CHO}^{\mathrm{SFS}}\right)$ cells. This transduction was accomplished at the department of Hematology, Hanover Medical School [1].

\section{Production test for TGFb-1}

The cells were verified via flow cytometry for the successful transduction. The selected method involves the specific intracellular detection of His-tag by the help of fluorescence-labelled antibody.

The fixation of $2 * 10^{5}$ cells was performed by $4 \%$ paraformaldehyde solution, cells were permeated with $0.1 \%$ saponin followed by an incubation of the cells in $100 \mu \mathrm{L}$ primary antibody. Afterwards the antibody was coupled to a Phycoerythrin (PE) labelled secondry antibody with a fluorescent character.

To control staining specifity, non trasfected $\mathrm{CHO}$ cells were used as negative control which was treated with the same procedure as transfected cells. The results of the

Institute of Technical Chemistry, Leibniz University of Hanover, 30167 Hannover, Germany

Full list of author information is available at the end of the article staining show that about $77 \%$ of the cells are successfully transfected.

For the localisation of TGFb-1 cell culture supernatant and cell pellets after lysis via ultrasonic, were analysed via western blot using a combination of mouse-anti-His-tag and goat-anti-mouse-IgG-AP-conjugate. The results indicate that only a part of the protein is secreted extracellulary and the rest is present intracellulary.

\section{Cultivation of $\mathrm{CHO}$ cell line ( $\mathrm{CHO}^{\mathrm{SFS}}$ )}

$\mathrm{CHO}$ cells were cultured in serum free ProCHO 5 with $1 \%$ penicillin/streptomycin (PAA) and $2 \% \mathrm{~L}$-glutamine solution (4mM). A $250 \mathrm{ml}$ spinner flask (rpm. 80) was used for cell growth starting with a cell density of 0.4 * $10^{6}$ cells $^{*} \mathrm{ml}^{-1}$ and a volume of $100 \mathrm{ml}$. The cultivation was carried out for 108 hours and medium was changed every 2-3 days. Samples were taken every 24 hour to determine cell density and viability. A maximal cell density of $1.8^{*} 10^{6}$ cells $/ \mathrm{ml}$ could be achieved with a viability of $80 \%$.

\section{Purification of TGF beta 1}

The supernatant of the culture was used, to perform the downstream processing.

The cells were separated by means of centrifugation and the clean supernatant was purified via heparin affinity chromatography (HiTrap TM Heparin HP columns, GE Healthcare).

The elution was performed using the binding buffer (10 $\mathrm{mM} \mathrm{NaH}_{2} \mathrm{PO}_{4}, \mathrm{pH}$ 7) in addition to a linear $\mathrm{NaCl}$ gradient (max. 2M).

Afterwards all protein containing fractions obtained by FPLC were analysed using silver stained SDS-PAGE. The results show that TGFb- 1 could be purified with a purity of $70-80 \%$.

\section{Conclusion}

The production and secretion of TGFb-1 in the $\mathrm{CHO}$ cell line $\left(\mathrm{CHO}^{\mathrm{SFS}}\right)$ was successfully performed. The
C Biomed Central

(c) 2011 Abdulkerim et al; licensee BioMed Central Ltd. This is an open access article distributed under the terms of the Creative Commons Attribution License (http://creativecommons.org/licenses/by/2.0), which permits unrestricted use, distribution, and reproduction in any medium, provided the original work is properly cited. 


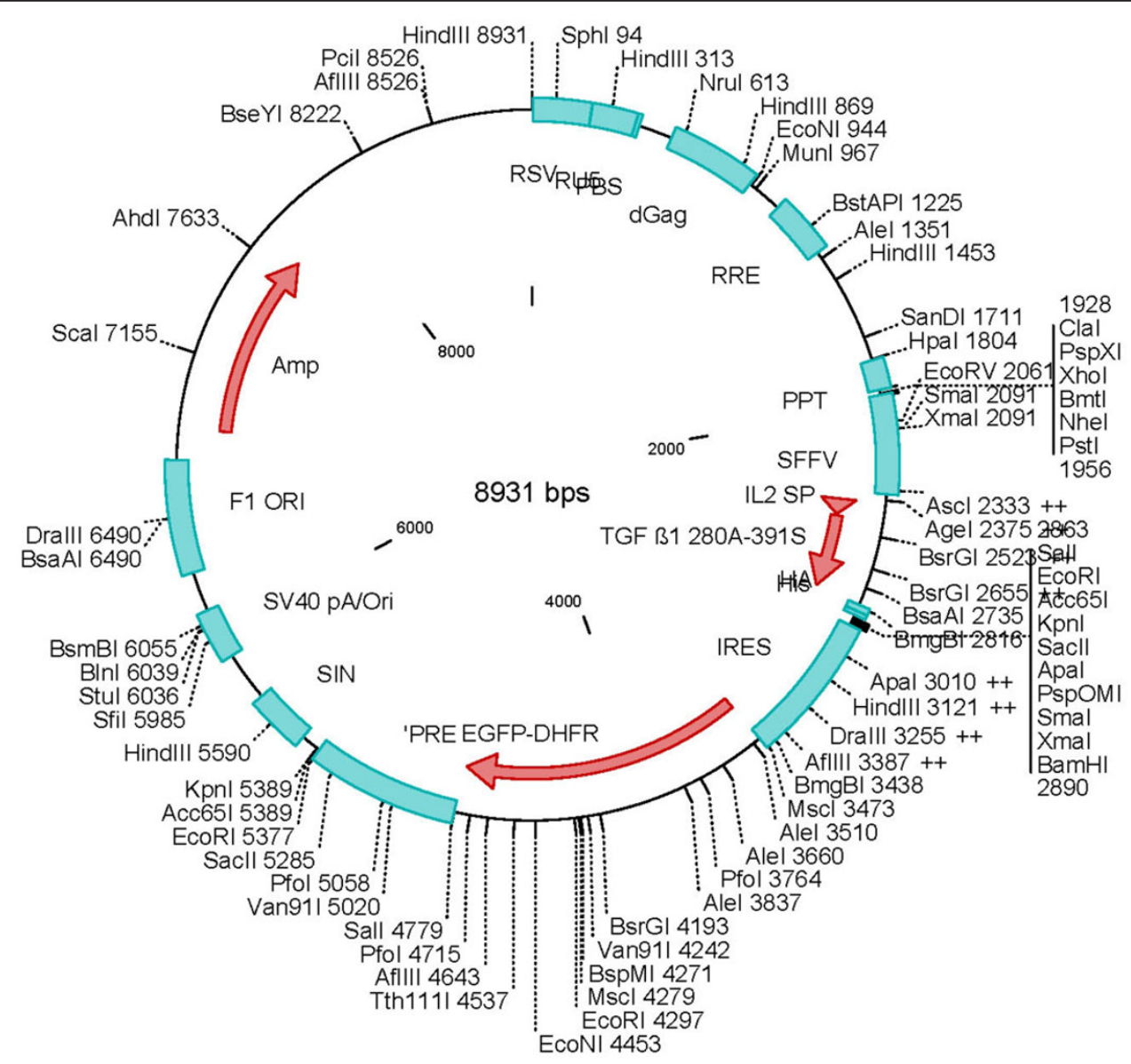

Figure 1 TGFb-1 vector used for the lentiviral transduction of $\mathrm{CHO}$ cell line $\left(\mathrm{CHO}^{\mathrm{SFS}}\right)$.

purification of protein was achieved using heparin affinity chromatography. Further upscaling of the procedure will be performed for achieving higher yield of the targeted protein.

\section{Acknowledgement}

This work was performed within the activities of the JRG "large scale cultivation" of the DFG cluster of excellence "Rebirth".

\section{Author details}

${ }^{1}$ Institute of Technical Chemistry, Leibniz University of Hanover, 30167 Hannover, Germany. ${ }^{2}$ Department of Experimental Hematology, Hanover Medical School, 30625 Hannover, Germany.

Published: 20 December 2011

\section{Reference}

1. Schambach A, Galla M, Modlich U, Will E, Chandra S, Reeves L, Colbert M, Williams DA, von Kalle C, Baum C: Lentiviral vectors pseudotyped with murine ecotropic envelope: Increased biosafety and convenience in preclinical research. Experimental Hematology 2006, 34:588-592.

doi:10.1186/1753-6561-5-S8-P134

Cite this article as: Abdulkerim et al:: Production and purification of TGFb-1 in CHO-Cells. BMC Proceedings 2011 5(Suppl 8):P134.

\section{Submit your next manuscript to BioMed Central} and take full advantage of:

- Convenient online submission

- Thorough peer review

- No space constraints or color figure charges

- Immediate publication on acceptance

- Inclusion in PubMed, CAS, Scopus and Google Scholar

- Research which is freely available for redistribution 